\title{
Energy for Rural Development in India: A Review
}

\author{
Sarvesh Kumar ${ }^{1}$, Navneet Sharma ${ }^{2}$, Chandra Prakash ${ }^{3}$, Ishrat Bano ${ }^{4}$ \\ ${ }^{1,4}$ Doon (PG) College Agriculture Science and Technology, Dehradun, India \\ ${ }^{2}$ International Water Management Institute, New Delhi, India \\ ${ }^{3}$ Baba Farid Institute of Technology, Dehradun, India
}

\begin{abstract}
Our nation can achieve its progress when the rural sector is uplifted as they constitute the major percentage of population. The progress should be achieved in several means, that is, infrastructure, electrification of villages, mechanization etc. The problem faced by villages of many states is that grid connectivity needed in centralized generation cum distribution system is either not feasible or is not cost effective. Several renewable sources of energy available in nature can be effectively used to serve different applications in rural sector like power generation, cooking, irrigation and water heating. Indian Government has come forward with new schemes and funding assistance in implementing such projects in both national as well as state levels. This paper presents the different technologies that can be adopted for improving the life of the rural sector.
\end{abstract}

Keywords: Energy, renewable, rural development,

\section{Introduction}

Energy is the core component in developing economy, in eradicating poverty and improving living standards. It contributes directly to meet both basic needs and more sophisticated human needs. India accounts for about one sixth of the world's population and about $40 \%$ of the people do not have access to modern energy. Out of the 87 million rural households not more than $30 \%$ have access to electric grids or modern cooking fuels. The people of the rural areas rely on kerosene for lighting and biomass fuels such as wood, animal dung and agricultural residues for cooking due to inadequate and unreliable power availability. The lack of access to modern energy has a negative impact on social and economic development and on the lives of the poor people. This is being increasingly recognized by the government and a high priority is being given to rural electrification so as to meet its economic, social, political and regional developmental goals. Although traditional strategies like fossil fuels based grid extension form a major part of energy supply in

India, several problems like storage of fossil fuel, environmental constraints and higher cost are associated. The centralized grid system is not always the most effective channel for energy distribution to remote rural areas also is more harmful to the environmental and requires more extensive infrastructure. The advent of renewable energy technology comes as a solution to these problems. Reports show that it is more cost effective to install a decentralized renewable energy technology to provide electricity in rural areas than extending transmission grid from a centralization system.

Renewable energy sources and technologies have potential to provide solutions to the long standing energy problems being faced by the country. To meet the energy requirement for a fast growing economy like India assured supply of energy is required. The renewable energy sources like wind energy, solar energy, biomass energy, tidal energy, geothermal energy etc. can be used to overcome the energy crisis in India. About $33 \%$ of Indians present energy needs are met from renewable sources.

This paper gives an overview of the energy consumption status in India, potential of renewable energy sources and their varied applications in the rural sector.

\section{Energy Trends in India}

India is one of the densely populated nations of the world with a population of more than one billion. In the coming decades, India will face energy shortages critically due to increase in energy prices and energy insecurity. India had a GDP growth rate of 9\% for the fiscal year 2007-2008 which makes it the second fastest emerging economy after china in the world. So there is an increasing demand for energy, which is currently satisfied mainly by coal, foreign oil and petroleum. These sources being non-renewable do not offer a permanent solution to the energy crisis and have negative impacts on environment. The time has thus come for the booming Indian economy to switch from non-renewable sources to renewable sources so as to achieve energy security.

The development and use of renewable energy sources and technologies are important for sustainable economic development of India. The expert consultation at Asia energy vision 2020 organized under world energy council agreed on energy demand projection in India up to 2020 as given in table 2.1 .

Table 2.1: Energy demand and its projection in India

\begin{tabular}{|c|c|c|c|c|c|}
\hline S. No & Source & Unit & $1991-92$ & $2009-10$ & $2020-21$ \\
\hline 1. & Electricity & TW-h & 231 & 725 & 1300 \\
\hline 2. & Coal & MT & 229 & 690 & 1345 \\
\hline 3. & Petroleum products & MT & 57 & 165 & 335 \\
\hline 4. & Natural gas & B Cu. m & 18.6 & 65 & 130 \\
\hline
\end{tabular}

The expert committee on integrated energy policy in its report (IEPR2006) has estimated that by 2032, primary commercial energy requirement in the country need would go up 4-5 times the current level, electricity generation

Volume 5 Issue 6, June 2016 www.ijsr.net 


\section{International Journal of Science and Research (IJSR) \\ ISSN (Online): 2319-7064}

Index Copernicus Value (2013): 6.14 | Impact Factor (2015): 6.391

installed capacity by 5.6-7 times the current level and oil requirement by 3-6 times the current level [1].

\subsection{Renewable energy in India}

Sustainability can be achieved in energy supply by promoting energy conservation measures and increased use of the renewable energy sources. India is determined to becoming one of the world's leading clean energy producers. As on October 2015, total thermal installed capacity stood at $195.6 \mathrm{GW}$, while hydro and renewable energy installed capacity totaled $42.5 \mathrm{GW}$ and $36.5 \mathrm{GW}$, respectively. At $5.8 \mathrm{GW}$, nuclear energy capacity had increased considerably which otherwise remained the same from 2010 - 15

For the 12th Five-Year Plan, a total of $88.5 \mathrm{GW}$ of power capacity addition is targeted; of which, $72.3 \mathrm{GW}$ constitutes thermal power, $10.8 \mathrm{GW}$ hydro power and $5.3 \mathrm{GW}$ nuclear power. The installed power capacity in India is shown in fig. 2.1 .

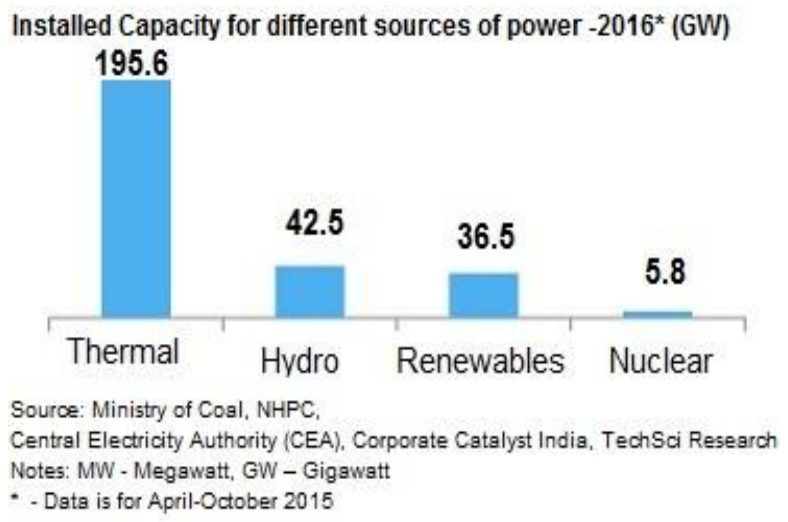

Figure 2.1: Installed power capacity in India The estimated renewable energy potential of India is listed in table 2.2.

Table 2.2: Renewable energy potential of India

\begin{tabular}{|c|c|c|}
\hline S. No & Source & Power(MW) \\
\hline 1 & Wind & 45000 \\
\hline 2 & Small hydro & 15000 \\
\hline 3 & Bio mass/energy & 25000 \\
\hline 4 & $\begin{array}{c}\text { Solar photovoltaic cell \& solar } \\
\text { thermal energy }\end{array}$ & $35 / \mathrm{km}^{2}$ \\
\hline \multicolumn{2}{|c|}{} \\
\hline \multicolumn{2}{|c|}{} \\
\hline
\end{tabular}

The renewable energy sources have been contributing to $7.7 \%$ of total electricity installed capacity in 2007. The renewable energy industry has been accepted to have a primary role for making our nation an energy secure one. Out of the estimated potential of 100,000 MW from renewable energy, only about $3500 \mathrm{MW}$ has been exploited till date. The major contribution to renewable energy investment comes from private sector applications. The government has been trying to support the renewable energy industry by launching supporting schemes and policies.

In the 11th five year plan, the Indian government has set specific target for renewable energy by 2012 that it is expected to contribute $10 \%$ of total power generation capacity and have a $4-5 \%$ share in the electricity generation. This indicates that the growth in renewable energy occurs at a much faster pace than traditional power generation, with renewable making up $20 \%$ of $70,000 \mathrm{MW}$ of total additional energy planned in the $11^{\text {th }}$ five year plan.

During the last two decades several renewable technologies have been deployed in rural and urban areas. Some of the achievement are given is table 2.3 along with the estimated potential of different renewable energy sources in India.

Table 2.3: Potential of renewable energy sources in India

\begin{tabular}{|c|c|c|c|}
\hline SL. no. & Source'system & Estimated ptential & Achierements (as on 30 September 2008) \\
\hline 1 & Aponer from ronewables & & \\
\hline A & Grid interative renewable pwast & (nw) & (MW) \\
\hline 1. & Wind power & 45,195 & $9521 \$ 00$ \\
\hline 2. & Biopower (agnocesidues and plantations) & 16881 & 65650 \\
\hline 3. & Bagasse cogeneration & 5000 & 99383 \\
\hline 4. & Small hydro (up to $25 \mathrm{MW}$ ) & 15,000 & 222099 \\
\hline 5. & Energy recowey from waste (MM) & 2000 & 5525 \\
\hline \multirow[t]{2}{*}{6.} & Solar photovoditaic pwer & & $2.12 \mathrm{MW}$ \\
\hline & Sob total (A) & s.7\% & 13,45059 \\
\hline B. & Captive|combined heat and power|distributed renewable power & & \\
\hline 7. & Biomess kogenerertion (non-tugzzse) & - & 136.70 \\
\hline 8. & Biomess gasifers & - & 10221 \\
\hline \multirow[t]{3}{*}{9.} & Energy recovery from waste & - & 31.07 \\
\hline & $\sin$ total (B) & & 26998 \\
\hline & Toel $(A+B)$ & \$47\% & 13,72057 \\
\hline ॥ & Remote villzge electrifiction & & 5379 villggess hamkts \\
\hline III & Decentralized energy yystems & & \\
\hline 10. & Family-type biogss plunts & 120 lath & 40.32 lakh \\
\hline \multirow[t]{6}{*}{11.} & Solar photowodtaic systems & $50 \mathrm{MW}^{\mathrm{km}} \mathrm{m}^{2}$ & $120 \mathrm{MWp}$ \\
\hline & i. Solar street lighting systems & & $70,474 \mathrm{pos}$ \\
\hline & ii. Home lighting ssstems & - & 4346992 mos. \\
\hline & iii. Solar lanterns & - & $697,419 \mathrm{mog}$ \\
\hline & iv. Solur pewer plant & - & 801MWp \\
\hline & v. Solar phostowltazic pumps & . & 7148 nos. \\
\hline \multirow{3}{*}{12.} & Solar thermel systems & & 4.78058 nos. \\
\hline & i. Solar water beating systems & 140) million $m^{2} \alpha$ colletax zee & 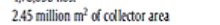 \\
\hline & ii. Solar cookers & - & 6.37 laths \\
\hline 13. & Wind pumps & - & 1342 nos. \\
\hline 14. & 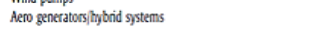 & & $72300 \mathrm{wW}$ \\
\hline $\mathrm{N}$ & Awareness programs & & \\
\hline 15. & Energy perks platils & - & 516 nos. \\
\hline 16. & Aditya Solar Shops & - & 269 nos. \\
\hline 17. & Renenevble Energy Cous & - & 521 nos. \\
\hline \multirow[t]{2}{*}{18.} & Distric Advisory Committes & - & 560 nos. \\
\hline & $M W=m e z z-w a t t ; m^{2}=s q u e$ & neter; $\mathrm{km}^{2}=$ kllowatt: & it peak \\
\hline
\end{tabular}

\subsubsection{Hydro power}

Hydro electric power refers to the energy produced from water (flowing in rivers etc.). Hydro power is a source of renewable energy that converts the potential or kinetic energy of water into mechanical energy in form of water mills, textile machines etc. or as electrical energy i.e.(hydro electricity generation).

In hydro power generation water stored in a dam is carried through penstock which turns the turbine. The turbine in turn is connected to generator where kinetic energy of water is converted to electrical energy. A typical hydropower generation plant is shown in fig.2.2.

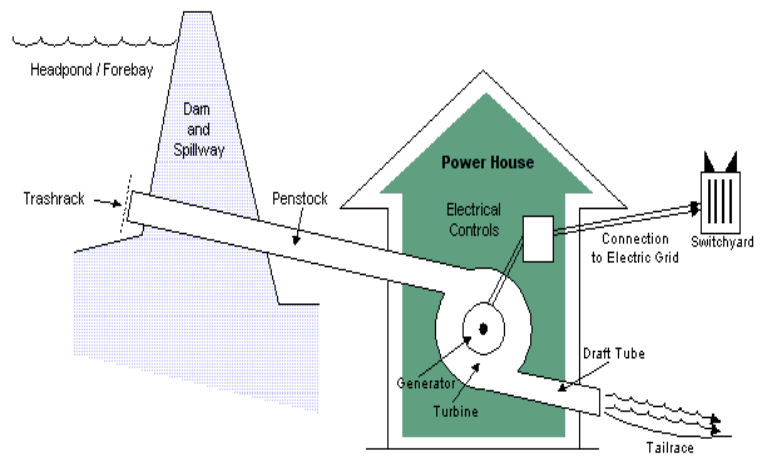

Figure 2.2: Hydropower generation plant

Only about $17 \%$ of the vast hydro potential of $150000 \mathrm{MW}$ has been tapped so far. India ranks fifth in terms of exploitable hydro potential of the world according to CEA (central electricity authority) [2].India is endowed with 


\section{International Journal of Science and Research (IJSR) \\ ISSN (Online): 2319-7064}

Index Copernicus Value (2013): 6.14 | Impact Factor (2015): 6.391

economically exploitable hydro power potential to the turn of $148700 \mathrm{MW}$. The basin-wise assessed hydropower potential in India is shown in table 2.4.

Table 2.4: Basin-wise hydropower potential in India

\begin{tabular}{lc}
\hline Basin/Rivers & $\begin{array}{l}\text { Probable installed } \\
\text { capacity (MW) }\end{array}$ \\
\hline Indus basin & 33,832 \\
Ganga basin & 20,711 \\
Central Indian river system & 4152 \\
Western flowing rivers of southern India & 9430 \\
Eastern flowing rivers of southern India & 14,511 \\
Brahmaputra basin & 66,065 \\
Total & 148,701 \\
\hline
\end{tabular}

Narmada Hydroelectric Development Corporation website.

In India, hydro power project with a station capacity of up to $25 \mathrm{MW}$ fall under the category of small hydro power (SHP). India has an estimated SHP potential of about 15000MW, of which about $11 \%$ has been tapped so far. The ministry of new and renewable energy (MNRE) supports SHP project development throughout the country. So far, 532 SHP project with an aggregate installed capacity of $1705 \mathrm{MW}$ have been installed. Beside these, 205 SHP project with an aggregate capacity of $479 \mathrm{MW}$ are under implementation.

\subsubsection{Biomass energy}

Biomass includes solid biomass(organic non fossil material of biological organics), biogas (a mixture of gas produced by methane-based bacteria acting upon biodegradable materials in an anaerobic environment and consists of methane, carbon dioxide and small amounts of other gases), liquid bio fuels (bio-based liquid fuel from biomass transformation, mainly used in transportation applications) and municipal waste (wastes produced by the residential, commercial and public services sectors and incinerated in specific installations to produce heat and/or power). Other common forms of biomass are sugarcane biogases in agriculture, pulp and paper residues in forestry and manure in live store residues. The potential of different biomass sources in India are shown in table 2.5 .

The common methods used to produce energy for biomass are:

1) Combustion

2) Gasification

3) Ferment ration

4) Anaerobic digestion

Table 2.5: Potential of biomass sources in India

\begin{tabular}{|c|l|r|}
\hline S.No & \multicolumn{1}{|c|}{ Source } & Potential $(M W)$ \\
\hline 1 & Agro residues and plantation & 1688 \\
\hline 2 & Biogases cogeneration & 5000 \\
\hline 3 & Energy recovery from wastes & 2700 \\
\hline
\end{tabular}

India attracts investment of overRs.600 crores every year, generating more than 5000 million units of electricity and yearly employment of above 10 million man-days in rural areas. The biomass production potential of some Indian states is given in table 2.6.
Table 2.6: Biomass potential of Indian states

\begin{tabular}{|c|c|}
\hline Indian States & Potential $(\mathrm{MW})$ \\
\hline A.P & 200 \\
\hline Bihar & 200 \\
\hline Gujarat & 200 \\
\hline Karnataka & 300 \\
\hline Maharashtra & 1000 \\
\hline Punjab & 150 \\
\hline Tamil Nadu & 350 \\
\hline U.P & 1000 \\
\hline
\end{tabular}

Some of the applications of biogas in rural area are:

- Low-cost fuel in for any heating purpose, such as cooking

- Lighting purpose

- To run any type of heat engine, to generate either mechanical or electrical power

- Biogas can be compressed, much like natural gas, and used to power motor vehicles

- Bio-slurry is an excellent fertilizer

\subsubsection{Wind Energy}

Wind is a widely distributed energy resource. Total world wind capacity at the end of 2006 was around 72,000 MW. Wind energy is being developed in the industrialized world for environmental reasons and it has attractions in the developing world as it can be installed quickly in areas where electricity is urgently needed. Wind energy is the fastest growing renewable energy source in the world. The worldwide installed capacity is growing at a rapid pace of over $30 \%$ per year due to declining cost, technological advances, and revenue for landowners, tax jurisdictions and consumer.

In many instances it may be a cost-effective solution if fossil fuel sources are not readily available. In addition there are many applications for wind energy in remote regions, worldwide, either for supplementing diesel power (which tends to be expensive) or for supplying farms, homes and other installations on an individual basis. The availability of wind varies for different regions. Wind resources can be exploited mainly in areas where wind power density is at least $400 \mathrm{~W} / \mathrm{m}^{2}$ at $30 \mathrm{~m}$ above the ground. An annual mean wind power density greater than $200 \mathrm{~W} / \mathrm{m}^{2}$ at $50-\mathrm{m}$ height has been recorded at 211 wind monitoring stations, covering 13 states and union territories, namely Andaman and Nicobar Islands, Andhra Pradesh, Gujarat, Karnataka, Kerala, Lakshadweep, Madhya Pradesh, Maharashtra, Orissa, Rajasthan, Tamil Nadu, Uttaranchal, and West Bengal. India's wind power potential has been assessed at 45,000 MW (Table 2.7). A capacity of $8757 \mathrm{MW}$ up to 31 March 2008 has so far been added through wind. India occupies fifth position globally in wind power capacity. Different types of Wind Power Generators used in India for Off grip Power generation are water-pumping windmills, aero-generators (a small wind electric generator having a capacity of up to $30 \mathrm{~kW}$ ) and wind-solar hybrid systems.

The essential requirements for the establishment of a wind farm for optimal exploitation of the wind are the following:

- High wind resource at particular site.

- Adequate land availability

- Suitable terrain and good soil condition

- Maintenance access to site 


\section{International Journal of Science and Research (IJSR) \\ ISSN (Online): 2319-7064}

Index Copernicus Value (2013): 6.14 | Impact Factor (2015): 6.391

- Suitable power grid nearby

- Techno-economic selection of specific turbines

- Scientifically prepared layout

Table 2.7: Estimated wind power potential in India

\begin{tabular}{|l|c|}
\hline \multicolumn{1}{|c|}{ State } & $\begin{array}{c}\text { Gross } \\
\text { Potential } \\
\text { (MW) }\end{array}$ \\
\hline Andhra Pradesh & 9063 \\
\hline Gujarat & 7362 \\
\hline Karnataka & 7161 \\
\hline Kerala & 1026 \\
\hline Madhya Pradesh & 4978 \\
\hline Maharashtra & 4519 \\
\hline Orissa & 1520 \\
\hline Rajasthan & 6672 \\
\hline Tamil Nadu & 4159 \\
\hline \begin{tabular}{l} 
West Bengal \\
\hline TOTAL
\end{tabular} & 32 \\
\hline $\begin{array}{c}\text { Total No. of Stations in operation at the } \\
\text { end of February 2006 }\end{array}$ & $\mathbf{4 6 , 0 9 2}$ \\
\hline $\begin{array}{c}\text { Total No. of Stations closed down in } \\
\text { March 2006 }\end{array}$ & $\mathbf{5 9}$ \\
\hline $\begin{array}{c}\text { Total No. of Stations Commissioned in } \\
\text { March 2006 }\end{array}$ & $\mathbf{1}$ \\
\hline $\begin{array}{c}\text { Total No. of stations in operation as on } \\
\text { 31st March 2006 }\end{array}$ & $\mathbf{5 9}$ \\
\hline \hline
\end{tabular}

\subsubsection{Solar Energy}

Solar energy is the most abundant permanent energy resource on earth and it is available for use in its direct (solar radiation) and indirect (wind, biomass, hydro, ocean, etc.) forms. Solar energy, experienced by us as heat and light, can be used through two routes: the thermal route uses the heat for water heating, cooking, drying, water purification, power generation, and other applications; the photovoltaic route converts the light in solar energy into electricity, which can then be used for a number of purposes such as lighting, pumping, communications, and power supply in un electrified areas. Solar air heating technology has been applied to various industrial and agricultural processes (e.g. drying/curing, regeneration of dehumidifying agents, timber seasoning, and leather tanning) and also for space heating; many types of solar dryers have been developed for use in different situations. Solar energy can be stored in batteries and used. In rural sectors also, street lighting can be done using such stored energy. Solar thermal technologies, particularly solar water heating system, solar cookers and solar generation systems are the most commercialized technologies among renewable energy technologies in India.

The MNRE, working in conjunction with the Indian Renewable Energy Development Agency (IREDA) to promote the utilization of all forms of solar power as well as to increase the share of renewable energy in the Indian market. This promotion is being achieved through $R \& D$, demonstration projects, government subsidy programs, and also private sector projects. The Prime Minister released the National Action Plan on Climate Change (NAPCC) on 30th June, 2008. The Plan proposes to start 8 missions, amongst which one is the National Solar Mission Solar thermal and solar photovoltaic technologies are both encompassed by the Solar Energy Program that is being implemented by the Ministry (regarded as one of the largest in the world) to utilize India's estimated solar power potential of 20 and 35 $\mathrm{MW} / \mathrm{km}^{2}$ solar thermal. India's overall potential for solar water heating systems has been estimated to be 140 million $\mathrm{m}^{2}$ of collector area. A Government scheme for 'Accelerated development and deployment of Solar Water Heating systems in domestic, industrial and commercial sectors' has been introduced, with the aim of promoting the installation of another million $\mathrm{m}^{2}$ of collector area during fiscal years 2005-2006 and 2006-2007. The scheme offers a number of financial and promotional incentives, along with other measures of support. The Government provides financial support for solar air heating/drying systems, and also for solar concentrating systems. Solar buildings have been promoted by the MNRE in an effort to increase energy efficiency; the state government in Himachal Pradesh has actively promoted the incorporation of passive solar design into building design. The Solar Photovoltaic Program (SPV) promoted by the Ministry for the past two decades, has been aimed particularly at rural and remote areas. Following the success of the country-wide SPV demonstration and utilization program during the period of the Ninth Plan, it is planned, with certain modifications, to continue it during the Tenth Plan (2002-2007). The Ministry has the objective that by 2010 they will all have access to power from renewable energy sources.

\subsubsection{Tidal energy}

Tidal energy is one of the best available renewable energy sources. The reserves of oil and coal are limited and rapidly dwindling. Besides, oil and coal cause enormous atmospheric pollution both from emission of greenhouse gases and from their impurities such as sulfur in the fuel. Tidal energy is clean and not depleting. These features make it an important energy source for global power production in the near future. To achieve this goal, the tidal energy industry has to develop a new generation of efficient, low cost and environmentally friendly apparatus for power extraction from free or ultra-low head water flow.

All existing tidal power plants use the same design that is accepted for construction of conventional river hydropower stations. The three principal structural and mechanical elements of this design are: a water dam across the Sow, which creates an antiracial water basin and builds up a water head for operation of hydraulic turbines; a number of turbines coupled with electric generators installed at the lowest point of the dam; and hydraulic gates in the dam to control the water Sow in and out of the water basin behind the dam. Sluice locks are also used for navigation when necessary. The turbines convert the potential energy of the water mass accumulated on either side of the dam into electric energy during the tide.

\subsection{Status of Rural Renewable Energy in India}

The global status in the adoption of rural renewable energy system is shown in table 2.8 . 


\section{International Journal of Science and Research (IJSR) \\ ISSN (Online): 2319-7064}

Index Copernicus Value (2013): 6.14 | Impact Factor (2015): 6.391

Table 2.8: Global status of rural renewable energy

\begin{tabular}{|c|c|c|c|c|c|}
\hline & 1 & 2 & 3 & 4 & 5 \\
\hline $\begin{array}{c}\text { Small hydro, } \\
\text { wind, PV, } \\
\text { biomass }\end{array}$ & China & India & Nepal & Vietnam & Sri Lanka \\
\hline $\begin{array}{c}\text { Water pumping, } \\
\text { Mechanical wind, } \\
\text { PV }\end{array}$ & Argentina & China & $\begin{array}{c}\text { South } \\
\text { Africa }\end{array}$ & Namibia & India \\
\hline $\begin{array}{c}\text { Solar Home } \\
\text { Systems }\end{array}$ & India & China & Thailand & Kenya & Sri Lanka \\
\hline Biogas & China & India & Nepal & & \\
\hline $\begin{array}{c}\text { Biomass } \\
\text { Gasification }\end{array}$ & India & China & & & \\
\hline
\end{tabular}

India recognizes the importance of expanding access to modern energy services for their rural areas through the development of renewable energy .In India, over 3000 remote and inaccessible villages and hamlets have been provided with basic electricity services through distributed renewable power system. India is the largest producer of world's rural solar home system and biomass gasification. India's installed capacity for small hydro was $1850 \mathrm{MW}$ as on 30 September 2006. Rural application of solar PV increased to cover 340,000 home lighting systems, 540,000 solar lanterns and 7000 solar power water pumps. There are 600,000 solar cookers in use. India achieved 70MW of small scale biomass gasification system or rural (off grid) power generation. Currently biomass helps to meet $70 \%$ of the of the basic energy needs in the rural areas veering almost $70 \%$ of the population in India. About 100,000 biogas plants and 16,530 SPV lighting system were installed which created a large no. of employment and income generation opportunities, especially in the rural areas. In addition $100 \%$ producer gas operated engines were developed and desolated in several villages for rural electrification. Over 150,000 sq. meters of collector area has been installed for solar water heating in the domestic, industrial and commercial sector in India. As a result the coverage of the cumulative installed collector area has increased to one million square meters.

\subsection{Renewable Energy for Environmental Sustainability}

The current pattern of energy use and economic growth has been creating lot of environmental problems - polluting the air, creating large quantities of waste, degrading biological systems and accelerating climate change. At the same time, the lack of access to energy services creates many social concerns, including poverty, ill health, unemployment and inequality. India stands fourth in the consumption of oil globally. About $70 \%$ of total greenhouse gas emissions are related to energy, mainly from the combustion of fossil fuels for heat, electricity generation and transport. There are several options to reduce green house gas emissions including energy conservation along with increasing efficiency, better energy management, cleaner production and consumption, and changes in lifestyles. Renewable and other more efficient technologies would also help mitigate climate change. Overall, countries can foster science-based decision-making that creates incentives for cleaner and more energy-efficient economic activities while increasing people's access to modern energy services.
Renewable energy development is considered in India to be of great importance from the point of view of long term energy supply security, environmental benefits and climate change mitigation. The Integrated Energy Policy report has recognized the need to maximally develop domestic supply options as well as the need to diversify energy sources. The Committee has placed emphasis on higher use of renewable in all forms of services. It is expected that the contribution from renewable in power generation alone can be of the extent of $60,000 \mathrm{MW}$ in the year 2031-2032.MNRE has included in its mission: energy security; increase in the share of clean power; energy availability and access; energy affordability and energy equity.

\subsection{India's Financing Environment for Rural Renewable Energy}

For nearly 40 years, India's significant efforts have gone into the design, development, field demonstration and largescale use of a number of renewable energy products and systems [3].

- In 1981, the Indian government established a Commission for Additional Sources of Energy (CASE) with the responsibility of formulating policies, and their implementation, programmes for development of new and renewable energy apart from coordinating and intensifying research and development in the sector.

- In 1982, CASE was incorporated in the Department of Non-Conventional Energy Sources, which, in 1992, became the Ministry of Non-Conventional Energy Sources (MNES) and was renamed as Ministry of New and Renewable Energy (MNRE) in 2006. India is the only country in the world that has an exclusive ministry which deals with new and renewable energy sources. MNRE supports the implementation of programmes, covering the entire range of new and renewable energies. The programme broadly seeks to supplement conventional fossil fuel-based power; reach renewable energy, including electricity, to remote rural areas for a variety of applications.

- The 9th, 10th and 11th Five-Year Plans clearly indicated that rural development and energy are the major goals for the plan periods. Along with the various MNRE technologies, decentralised energy planning through Integrated Rural Energy Programme is also in progress.

- In 2003, India's government enacted the Electricity Act. The Act is the most important legislative development which has stimulated the recent growth in renewable power in India. The Act recognises the role of renewable energy technologies for supplying power to the utility grid as well as in standalone systems.

- The financing channels of rural renewable energy of India mainly include government finance, international funding, commercial banks and non-bank financial institutions, public stock markets and private-sector finance.

- A number of financing instruments have been used to facilitate the development of rural renewable energy like cash grants, setting up of Renewable Energy Services Companies (RESCOs), low interest and long term loans, joint ventures with companies in other countries, subsidies, import duty reductions for renewable technologies and reduction in Value Added Tax. 


\section{International Journal of Science and Research (IJSR) \\ ISSN (Online): 2319-7064}

Index Copernicus Value (2013): 6.14 | Impact Factor (2015): 6.391

\subsection{Major Achievements}

India's major achievements on renewable energy development can be summarized as follows:

- Over 4200MWgrid power from wind, small hydro, biomass and solar energy.

- 3600 remote villages/hamlets, including those in Sunder bans, Bastar, Ladakh and the North East electrified through solar energy.

- Largest solar-steam cooking system for15000 persons/day set up at TirupatiTirumalaDevasthanam.

- $\quad$ 07lakh square meter collector area solar water heating systems installed.

- $\quad 3.5$ million Biogas plants installed for cooking and lighting applications.

- $\quad 35$ million improved wood stoves in rural homes.

- Integrated Rural Energy Program implemented in 860 blocks.

- $\quad 30 \mathrm{MW}$ capacity Solar Photovoltaic products exported to various developed and developing countries.

- Rs.25, 000 million direct subsidy given so far to beneficiaries/ users of renewable energy systems and devices, including subsidy for grid connected renewable power projects.

- Centre for Wind Energy Technology set up as a scientific and industrial research organization for wind resource assessment, equipment certification and R\&D at Chennai in Tamil Nadu.

\subsection{Some Case Studies}

\subsubsection{World's Largest Solar Steam Cooking System at Tirumala, Andhra Pradesh}

The world's largest solar steam cooking system has been installed by the Tirumala Tirupathi Devasthanam (TTD) at Tirumala in Andhra Pradesh. The system has a capacity to prepare food for 15,000 people/day and employs automatic tracking solar dish concentrators, which convert water into high pressure steam. The steam thus generated is being used for cooking purposes in the kitchen of TTD. It has been hooked up with the existing boiler working on diesel so as to make the system reliable under all climatic conditions [4].

The system has been designed to generate over $4000 \mathrm{kgs}$ of steam/day at 180 degree centigrade and $10 \mathrm{~kg} / \mathrm{sq} \mathrm{cm}$ which is sufficient to cook two meals for around 15,000 persons. It is modular in nature and consists of 106 automatic tracked parabolic concentrators arranged in series and parallel combination, each of 9.2 sq meter reflector area. Each unit of concentrators is connected to a central steam pipeline going to the kitchen. The system is made of indigenous components and the reflectors are of acrylic mirrors having reflectivity over $75 \%$. Its installation was completed during September 2002 and was inaugurated on 11th October 2002. The system is expected to save around 1, 18,000 litres of diesel per year, valued at Rs. 2.3 million.

The total cost of the system is about Rs. 110 million, which includes back up boiler, utensils and annual maintenance contract for five years. The system has been installed by $\mathrm{M} / \mathrm{s}$ Gadhia Solar Energy Systems, Valsad under a demonstration scheme of MNES with $50 \%$ financial support. Balance of the cost has been borne by the TTD trust. A total of 6 such systems have been installed in the country. This technology could be very useful at places where rice is the staple food and cooking is done on a very large scale.

\subsubsection{Bagasse based Cogeneration System}

A17 MW co-generation power project set up by M/s Kakatiya Cement Sugar \& Industries Ltd., in 2002 at Peruvancha village, KallurMandal, Khammam District, Andhra Pradesh. The project is the first of its kind for a sugar mill. A high pressure boiler of 87 ata./515 deg $\mathrm{C}$ has been installed, which ensures high energy efficiency \& better utilization of bagasse resulting in more steam and hence more electricity.

The project envisages generation of power to meet captive sugar plant requirements, cement plant requirements and export of about 10.85 MW of surplus power during season and 14.70 MW during off-season, to the State grid. The project uses bagasse generated from the crushing operations of the sugar mill during season, and stored bagasse, cane trash and coal during off-season. The project was completed in a record period of 18 months. It achieved a PLF of around $90 \%$ in the very first year. The cost of the co-generation project was Rs. 501.7 million. The technology used was indigenous, except for the turbo-generator, which was imported. The project has generated direct employment opportunities to about 100 persons and has also contributed to economic development of the area.

\section{Conclusions}

Energy security, economic growth and environment protection are the national energy policy drivers of any country of the world. The concerns on energy crisis can be solved to a great extent by the adoption of renewable energy sources for electrification and to meet other energy needs. Therefore increased focus is being laid on the deployment of renewable power that is likely to account for around $5 \%$ in the electricity-mix by 2032. Alternate fuels, essentially biofuels, are proposed to be progressively used for blending with diesel and petrol, mainly for transport applications. Specific measures are being increasingly adopted to promoting deployment, innovation and basic research in renewable energy technologies, resolving the barriers to development and commercial deployment of biomass, hydropower, solar and wind technologies, promoting straight (direct) biomass combustion and biomass gasification technologies, promoting the development and manufacture of small wind electric generators, and enhancing the regulatory/tariff regime in order to main stream renewable energy sources in the national power system. Finally, renewable energy provides enormous benefits and can contribute significantly in the national energy mix at least economic, environmental and social costs and it is expected that the share of renewable energy in the total generation capacity will increase in future. The adoption of renewable energy technologies have particular significance in the rural sector which are discussed in the paper. The energy needs once met will in turn lead to the improvement of overall standard of living of the people and thereby nation's progress. 


\section{References}

[1] A. Kumar, K. Kumar , N. Kaushik , S Sharma, S. Mishra, Renewable energy in India: Current status and future potentials, Renewable and Sustainable Energy Reviews, 14, 2010, 2434-2442.

[2] Anoop Singh. A market for renewable energy credits in the Indian power sector, ScienceDirect, Renewable and Sustainable Energy Reviews 13 (2009) 643-652.

[3] D. Dey, Energy and Sustainable Development in India, Proc. Of Helio international, 2005/2006.

[4] H. Lund, Renewable energy strategies for sustainable development, Energy 32, 2007, pp. 912 - 919.

[5] M. Goyal and R. Jha, Introduction of Renewable Energy Certificate in the Indian scenario, Renewable and Sustainable Energy Reviews 13, 2009, pp. 1395 1405

[6] N.H. Afgan, D.A. Gobaisi, M.G. Carvalho and M. Cumo, Sustainable energy development, Renewable and Sustainable Energy Reviews 2, 1998, pp. 235 286.

[7] P. Meisen, Overview of Renewable Energy Potential of India, www.geni.org.

[8] www.mnre.gov.in

[9] www.powermin.nic.in.

[10] www.cea.nic.in

[11] The Indian Electricity Act, 2003.

Volume 5 Issue 6, June 2016 www.ijsr.net 